UDC 627.4:504.06

Margarita M. Radomska, PhD, Associate Professor of the Department of Ecology

ORCID ID 0000-0002-8096-0313 e-mail: m.m.radomskaya@gmail.com

Oleg V. Ryabchevsky, Teaching assisstant of the Department of Ecology

ORCID ID 0000-0002-5901-4365 e-mail: arnem@ukr.net

VeronikaV. Vologzhanina, Postgraduate student of the Department of Ecology

e-mail: ver.vologzhanina@gmail.com

Viktoriia V. Kovalska, Student of the Department of Ecology

ORCID ID 0000-0002-5489-7787 e-mail:vika_kovalska98@ukr.net

National Aviation University, Kyiv, Ukraine

\title{
THE EIA GAP ANALYSIS FOR THE PROJECT OF DREDGING WORKS AT THE SOUTHERN BUG RIVER
}

\begin{abstract}
The transformation of the Southern Bug river ecosystem for the revival of navigation activity has been considered in the paper from the point of indirect impacts on the environment. The method of gap analysis widely used in various branches of science has been applied to determine the omitted issues of the dredging works at the river basin. The analysis has showed that despite a range of important benefits, including promotion of agricultural and constructional materials production development, reduction of on-land cargo traffic and growing incomes to the local budget, the implementation of the project will cause additional negative effects, not considered in the official process of environmental impacts assessment. The most important problems, requiring further attention and mitigation, are intensification of erosive processes, changes of air and water quality, transformation of river biocenosis and climate of the area, as well as management of extracted bottom sediments.
\end{abstract}

Keywords: biocenosis; environmental impacts assessment; gap analysis; dredging works; waste management; ecosystem transformation

\section{Introduction}

The multipurpose use of the river forms high technogenic pressure on their ecosystem and coastal area. Considering the great importance of rivers in the economy and life of population, the analysis of the dynamics, variability, features of formation, and development of river ecosystems are important for the prognosis of their condition and development of recommendations for the rational use of water resources. Rivers are also intensively transformed for various economic purposes, including construction of channels, hydrotechnical and water intake or discharge structures, fishery and irrigation facilities, etc. These transformations have significant effect on the function ability of the river ecosystem and its biotic components, leading to increasing pollution and eutrophication.

The Southern Bug flows through Khmelnitsky, Vinnitsa, Kirovograd, Odessa and Mykolayiv regions, which are characterized with developed industry and agriculture, consuming river water for various purposes [1]. Therefore, the problem of conservation and rational use of natural resources of the Southern Bug is important at the level of 7 administrative regions and country as a whole.

(C) M.M. Radomska, O.V. Ryabchevsky, V.V. Vologzhanina, V.V. Kovalska, 2018 


\section{Formulation of the problem}

Until recently, the Southern Bug was used quite intensively for navigation up to the town of Voznesensk. Currently, there are few cargo ships and no passenger piers and navigation signs [2]. The lower channel of the Southern Bug is characterized with a slowing flow rate, but accelerates before the mouth of the river Mertvovod and the town of Novaya Odessa. Near the city of Mykolayiv, the width of the channel reaches $2 \mathrm{~km}$ and its current practically stops and numerous small islands are formed. As a result the industrial shipping is difficult on the river.

The project of shipping activity revival at the Southern Bug has been initiated by the company Nibulon. Their plan is to improve navigation on the Southern Bug at the section from Voznesensk to Mykolayiv. This is a part of the investment project "The Revival of Navigation on the Dnipro and the Southern Bug Rivers" [3].

The Southern Bug in the length of $134 \mathrm{~km}$ from the city of Mykolayiv to the village of Aleksandrovka, Voznesensky district of the Mykolayiv oblast is included in the list of inland waterways of Ukraine, belonging to the navigable category (the list was approved by the resolution of the Cabinet of Ministers of Ukraine of June 12, 1996, № 60) [1]. This project will provide the restoration of navigation at the Southern Bug for the distance of $102.2 \mathrm{~km}$ between the Varvarovsky road and the Voznesensky bridges. It involves the construction of elevators and river terminals, creation of special fleet, development of water transport infrastructure, including dredging works and the construction of hydro-technical structures $[4,5]$. Improvement of shipping conditions at the Southern Bug is aimed at developing the infrastructure of the region, including 11 local councils, being directly acquainted with project. The public opinion, as well as the attitude of state bodies of executive power (Mykolaiv State Regional Administration, Administration geology and mineral resources of Ukraine, State environmental expertise and State sanitary and epidemiological expertise) was positive [4]. However, numerous claims from scientists and local NGOs insist on incomplete character of the environmental analysis and needs additional considerations.

The main aim of the research was to identify the main environmental consequences of dredging on the state and dynamics of natural complexes in the lower flow of the Southern Bug.

\section{Methods and materials}

In management literature, gap analysis involves the comparison of actual performance with potential or desired performance [6]. In other words, it is the approach to define, how to use available resources for the best results. It is also a common approach in marketing research, aimed at definition of the usage gap between the total potential for the market and actual current usage by all consumers in the market [7]. In scientific application, gap analysis is more commonly attributed to the definition of voids and defects in spatial information, in particular borders of various landscapes, defined from the satellite and map images [8]. In a conservation context, gap analysis is a method to identify biodiversity (i.e., species, ecosystems and ecological processes) not adequately conserved within a protected area network or through other effective and long-term conservation measures [9, 10]. It has developed over the past 15 years in response to recognition that protected area systems of all types and in all parts of the world currently do not fully protect biodiversity [10]. 
The gap analysis may also refer "gap" as the information needed for successful performance of any project. This way it looks at two types of information needs: information gaps and communication gaps, for example, in the plans for the strategic development [11]. "Information gaps" represent the lack of existing data to provide the needs of an analyst, while "communication gaps" stand for the problems and obstacles for the transfer and exchange of knowledge between involved parties. The results of the survey provide a plan of further research and communication efficiency improvement [11].

Gap-analysis is the process of structuring and comparing two different situations or states in order to determine the difference or "gap" that exists between them. Once the "gap" is understood - and possibly also the "distance" between the states measured or otherwise assessed - it may then be possible to identify the steps or processes required to bridge the gap [12].

Here we offer to use gap analysis as a tool for the evaluation of the environmental impacts assessment quality. The work, conducted for the development of the EIA report, is often a subject for criticism from all stakeholders. The investors call down the detailed analysis as time and money consuming, while the local communities are more interested in benefits analysis, and scientists are notice some omitted factors and elements of impacts, claimed to be decisive for the project to be acceptable from the environmental point of view.

The following gap analysis is based on the best environmental practice principles and professional judgments. It is open to discussion and suggestions are invited. Therefore, we must note that the results are not statistically representative, but are intended to be descriptive in nature. Nevertheless, they highlight the major assessment gaps for the projects of this type and suggest research efforts, which should be given priority to cover all the issues important for the environment protection.

\section{The current condition of the Southern Bug water}

Southern Bug is the third largest river in Ukraine flowing from its central and southern regions through the forest-steppe and steppe zone [13].

In 2004-2005, the scientists of the Vinnytsia National Technical University called the State Water Management Commission to create a system of support for making managerial decisions for the Southern Bug River basin using GIS technologies [14]. According to the information provided by the Laboratory of Analytical Control of the State Administration of Ecological Resources in Vinnytsia Oblast, the water quality in the Southern Bug River and its tributaries, for 2003-2008, was characterized with the following indicators: the oxygen regime was satisfactory (the content of dissolved oxygen was within the range of 7.1 to $10,8 \mathrm{mg} \mathrm{O}_{2} / \mathrm{dm}^{3}$ ), water hardness average $\left(3.6-8.0 \mathrm{mg}-\mathrm{eq} / \mathrm{dm}^{3}\right)$, pollution with organic compounds was observed (biological oxygen demand (BOD5) fluctuated within the range of 2.11-5.4 $\mathrm{mg} \mathrm{O}_{2} / \mathrm{dm}^{3}$, which 1,02-3,03 times exceeds the MPC, in all directions there was increased iron content (2.1-5.6 MPC), manganese (1.6-4 MPC) and copper (up to 2 MPC) [15].

In the next three-year period (until 2011), the state of the waters of the upper flow of the Southern Bug River was characterized with predominantly water II and III quality classes, with a certain tendency to decreasing levels of chemical pollution due to reduction of wastewater discharges [16]. The worst indicators are at the level 
"above the standard" and "very high" (16-49\%) are near Yuzhnoukrainsk town, Sliven village, Ingul river, and city of Mykolaiv [17].

The content of cesium-137 and strontium-90 is well below the permissible levels, and the level of radioactive safety of the river is in general satisfactory [17].

The maximum concentration of nitrites is $0.30-0.52 \mathrm{mg} / \mathrm{dm}^{3}$, nitrates are 5.3-9.7 mg/dm ${ }^{3}$, which are much lower than the MPC for drinking water reservoirs, but the ammonium nitrogen content 1-1.8 MPC for reservoirs of commercial drinking water use and 0.44-2.5 MPC for fish-water reservoirs [18].

The main negative impacts on the river water are directly related to the uncontrolled ponds drawing down on the tributaries of the Southern Bug (188 reservoirs and 8005 ponds are located in the basin of the river) and the activity of urban water management facilities, as well as discharges of industrial enterprises (mainly mines and fish enterprises) [19]. But in general, the water of the river is, according to the most chemical indicators, except BOD and color, safe (II and III quality class) at 16 main observation sites and can be used for drinking needs [19].

At the same time, the analysis of graphs of water levels fluctuation and the dynamics of water pollution indexes shows a tendency to increasing levels of pollution of the river with the increasing water content [16]. Given this, the issue of preserving the water quality and the integrity of the river system of the Southern Bug with the deepening of its channel and the potential increase in water content is extremely relevant.

\section{The analysis of the project activity}

As it is stated by the officials of the Nibulon Company the theme of water transport competitiveness in Europe is clear, as it is recognized to be the most economical and environmentally friendly mode of transport. In Ukraine, unfortunately, the issue of water transport development is still open and unresolved, as well as the accompanying issues of the river transport arteries revival.

The company "Nibulon" found its way out from the difficult situation by launching an investment project, the full realization of which will support the development of agrarian and seafaring industry of Ukraine and the key waterways of the state.

This project involves the creation of cargo fleet, the construction of transport infrastructure for storage and shipment of grain, the reconstruction of gateways, and the improved navigable conditions of waterways. Moreover, the presence of significant mineral reserves in Ukraine and the Mykolaiv region in particular (granite, sand, gravel, etc.) can provide a stable demand for cargo traffic by the Southern Bug River [20].

In order to increase the profitability of water transport, it is necessary to ensure the movement of ships in the Southern Bug with higher load-carrying capacity and "river-sea" class. This will enable direct connection of the Dnipro-Bug region seaports for the purpose of loading large vessels. The essential condition for such changes is precisely the improvement of shipping conditions of waterways from the city of Voznesensk to the city of Mykolaiv.

The substantiation of the need for project activity by the company "Nibulon" has been also connected with the environmental factors. Thus, the Southern Bug 20 years ago had a depth of about $3 \mathrm{~m}$ and was navigable, but from year to year the rubbing of the river increases and at some points reaches $5 \mathrm{~cm}$ per year. Today, the Southern 
Bug River is a wide valley with low, reedbed waterlogged shores with relief, formed by landslide and erosion processes, blackened bottom and widespread algal blooms. The average depth of the river is $1.65 \mathrm{~m}$, and in places - up to $1 \mathrm{~m} \mathrm{[5].} \mathrm{Every} \mathrm{year,}$ the water volume is getting lower, it gets warmer, and hence the amount of soluble oxygen in water decreases, leading to massive fish kills, development of reed, which in turn causes stagnant phenomena and the spread of rotten bacteria. As a result, the river gradually swamps and ceases.

The first stage of the project involved cleaning up the depths of the ship's passage to the depths of $2.40-2.30 \mathrm{~m}$. The bottom sediments extracted are accumulated in 18 shore dumps located within the territorial boundaries of three districts: Voznesensky, Novodeisky and Mykolaiv, outside of settlements.

At the beginning of April, 2018, the Company completed the next stage of dredging works. The work was carried out with the help of the unique self-propelled super-heavy dredging vessel "Mykolayivets" constructed last year at the shipyardrepair plant "Nibulon" for the deepening of the Dnieper, Southern Bug, as well as the water areas of ports and terminals in order to ensure the efficient operation of the company fleet. The most important element of this stage was the removal of the Konstantinovsky whitewater, the largest limiting rapid of the Southern Bug at the project section. As it was planned, the guaranteed bearing depth for ships run was increased from $2 \mathrm{~m}$ to $2.5 \mathrm{~m}$ [21].

By the middle of June the Company will to start dredging works on the Dnieper, during the construction of new transshipment terminals of the company in Zaporizhzhia and Dnipro regions, and in autumn "Mykolaivets" will return to Southern Bug and complete the dredging on the site from the city of Nova Odesa to Voznesensk, providing a depth of $2.4 \mathrm{~m}$ [21].

The Nibulon Company project is in the mainstream of rivers reviving practice in Europe, aimed at restoration of natural territories, in particular by managing river basins and creating coastal structures, which provide stabilization of the hydrological regime in the river, improvement of the living places of aquatic organisms, promotes formation of aesthetic and investment attractiveness of coastal areas. Such projects have been successfully implemented in Germany, the Czech Republic, and Great Britain today [22].

The positive results for the region, according to the Project substantiation include:

- bringing the annual volumes of transportation by the river to 1 million tons of grain and oilseeds, and consequently the removal of 1 million tons of cargo from the highways;

- in the long run, the river will transport up to 1 million tons of constructional materials;

- the Southern Bug opening for investors;

- reducing the cost of cargo transportation and increasing the profitability of freight transport by water;

- reducing the load on railways and highways and the technogenic pressure on the adjoining environment;

- loading by the metallurgical, shipbuilding, ship repair enterprises of Ukraine due to the demand for the construction of modern tug and cargo fleet, reloading terminals;

- creation of new workplaces and increased budget incomes; 
- attraction of additional investments into agrarian, maritime and related industries, stimulation of their development;

- solving the issue of creating and securing modern shipping safety conditions [4].

In order to minimize the negative impacts from the project activity on the natural environment, the company initiated a range of mitigation activities and monitoring process. However, the analysis of the impacts, covered by mitigation activities, shows a range of gaps in the process of assessment.

\section{Results and discussions}

According to the EIA material, presented by the Nibulon Company, the major impacts on the environment are limited to the deterioration of water organisms living conditions, noise pollution and relocation of bottom sediments to the surface [23]. Thus, the degradation of hydrobiontes living conditions include temporary degradation of water quality - increased turbidity and temperature, change of hydrochemical conditions; and loss of some fodder species (plankton and benthos). To address these impacts, the project included the resolution to conduct dredging works in the non-peristal period and release of the most common fish fries into the river, fulfilled in November, 2017 [24].

As for the noise pollution from dredging mechanisms, it was considered moderately hazardous for local fauna. The air pollution produced by industrial dredging equipment is also considered to be of temporary character.

As for the impacts of the exposed bottom sediments on the environment, the company initiated the tests of the extracted material by certified laboratory to control the level of radioactivity, reaction and content of nutrients. According to the conclusions of the Mykolayiv branch of the State institution "Soil protection institute of Ukraine" bottom sediments are of limited application as organic fertilizers due to alkaline reaction, but at the same time suitable for growing perennial grasses and forestation, as the content of nutrients is sufficient and level of natural radioactivity is below the threshold.

However, the analysis of the project materials included in the section of the EIA, developed by the Nibulon Company, has defined the following gaps in the assessment, which must be considered in details and included into the plan of mitigation activities for the project:

1. Consequences of riverbed dredging for hydrological regime of the river - this is referred to increased flood risk, intensified coastal erosion, flow rate and discharge changes.

2. Promotion of erosion and exogenic geological processes due to changed hydrological regime, which creates threats to engineering structures.

3. Long-term changes of water quality, which is more prominent effect than the exposure of bottom sediments and their accumulation on the surface: the growing amount of suspended matter and decrease in oxygen content will increase the water trophic status and water pollution via resuspension of bottom sediment containing toxic substances, particularly in the river lower flow and estuary.

4. Transformation of river biocenosis, which is not limited to changes of fish diversity and biomass and involves formation of new biocenosis and complete loss of coastal ecosystems, threatening to a few dozens of protected species. 
5. Impacts on recreational potential - changes of riverbed parameters will definitely reduce the possibility to conduct organized and non-organized recreational activity.

6. Influence on the air quality, will have a long-term character as it will not be limited only to the technical equipment emissions: emissions of new river traffic are similar to that of heavy land transport and include number of pollutants. This is also true for the noise pollution, which may potentially affect 22360 people within the impact area.

7. Hidden cost of the project - once the dredging has been started, it must be repeated after every extreme flood, as the river silts up again.

8. Impacts on microclimate conditions due to reduction of vegetative cover, changes of air humidity, air circulation patterns and temperature of the boundary air layer at the contact with water.

9. Absence of sustainable practices of bottom sediments management: the extracted material is not suitable for use in agriculture, but our research shows that it is possible to use these sediments in the treatment of industrial wastewaters, in particular those, containing heavy metals.

Thereby, a special feature of hydrotechnical works effect on natural complexes is the creation within the territory of the influence of new ecosystems that have a different qualitative and quantitative level of the cycle of substances in nature. This adversely affects animals' way of life and changes their seasonal migration ways, places of watering, wintering conditions, searching for food, nesting conditions of birds, etc. Fluctuations of water levels adversely affect the habitats of small animals and intensify geological transformations of the territory.

The real task for the project of navigation revival is to obtain its economic gains and benefits without destructing natural ecosystem services, provided for many years and centuries before. In this line it is important to account the gaps mentioned above and minimize the manifestation of dangerous geological processes, air and water quality degradation and wild habitats destruction. We could also recommend investing efforts in the development of recreation infrastructure and considering best available waste management practices - this will not need high additional cost, but on the contrary will possibly give additional revenues to the Company-investor.

\section{Conclusions}

Due to the fact that intensive economic activity is usually concentrated in river ecosystems, they undergo strong anthropogenic pressure, causing their degradation and destruction or significant violation of ecological links in nature. The development of rivers resource potential is accompanied with the loss of the natural components quality (soils and water foremost) and collides with other types of socioeconomic use, including aesthetic, landscape and recreational aspects.

The project of the Southern Bug dredging is of high economic and social importance for Ukraine, as it will enable low-cost and efficient transportation of goods and passengers, and provide new work places and budget incomes for local communities. In a long-term perspective the navigating activity at this river will become a good practice for other regions of the country and contribute to the development of the state ship industry. 
However, the economic and environmental significance of the Southern Bug raises requirements to the completeness and quality of the potential environmental impacts assessment.

The gap analysis applied for the evaluation of the EIA performance quality has showed a range of issues, missing in the assessment process. Thus, the residual impacts, as they are mentioned in the official EIA materials on the Project, include only temporary increased turbidity of the water and noise level, as well as formation of sludge storage sites on the territory of local settlements. However, this approach to the assessment of potential consequences doesn't account impacts on microclimate, geological processes, air and water quality, bioproductivity of ecosystem living matter and human health (in terms of recreation possibilities limitation and environment pollution). Separate important drawback is an absence of the sludge management plan.

So, the approach to the assessment of potential consequences of the project was not rigorous enough and the proposed plan needs further analysis and considerations to reduce the intensity and diversity of the potential impacts.

\section{REFERENCES}

1. Паламарчук М.М. Водний фонд України. Довідковий посібник / М.М. Паламарчук, Н.Б. Закорчевна. - Київ: Ніка-центр, 2001. - 392 с.

2. Вишневський В.І. Гідрологічні характеристики річок України / В.І. Вишневський, О.О. Косовець. - Київ: Ніка-центр, 2003. - 324 с.

3. Судноплавний потенціал Південного Бугу [Електронний ресурс] // Прес-центр Нібулону. - 2015. - Режим доступу: http://www.nibulon.com/news/novinikompanii/sudnoplavnii-potencial-pivdennogo-bugu.html

4. Інформація для стейкхолдерів компанії (днопоглиблювальні роботи на р. Південний Буг) [Електронний ресурс] // Прес-центр Нібулону. - 2015. - Режим доступу: http://www.nibulon.com/data/investiciina-diyalnist/dlya-investoriv/informaciya-dlyasteikxolderiv-kompanii2.html.

5. Обміління Південного Бугу - загроза для екології Миколаївського регіону [Електронний ресурс] // Прес-центр Нібулону. - 2015. - Режим доступу: http://www.nibulon.com/news/novini-kompanii/obmilinnya-pivdennogo-bugu-zagrozadlya-ekologii-mikolaivskogo-regionu.html.

6. Lowry T. Management Gap Analysis: A Case Study of Groundwater Resource Management in New Zealand / Thomas Lowry, John Bright, Murray Close, Christina A. Robb, Paul A. White, Stewart G. Cameron, // International Journal of Water Resources Development. - 2003. - No. 19. - P. 579-592. doi: 10.1080/0790062032000161382.

7. Day G.S. Closing the Marketing Capabilities Gap / George S. Day // Journal of Marketing. - 2011. - Vol. 75. - P. 183-195

8. Jennings M.D. Gap analysis: concepts, methods, and recent results / Michael D. Jennings // Landscape Ecology. - 2000. - No 15. P. 5-20.

9. Arturo H. Ariño. Best Practice Guide for Data Gap Analysis for Biodiversity Stakeholders / Arturo H. Ariño, Vishwas Chavan, Javier Otegui. -Pamplona: Global Biodiversity Information Facility, 2016. -41 p.

10. Scott M.J. GAP Analysis: A Geographic Approach to Protection of Biological Diversity / M.J. Scott, F.W. Davis, B. Cusuti, R. Noss, B. Butterfield, C. Groves, H. Anderson, S. Caicco, F. D'Erchia, T.C. Edwards, J. Ulliman, R.G. Wright // Wildlife Monographs. - 1993. - No.123. - P. 1-41.

11. Tedsen E. Gap Analysis Report. Preparatory Action, Strategic Environmental Impact Assessment of development of the Arctic / Tedsen Elizabeth, Arne Riedel, Katherine 
Weingartner, Roberto Azzolini, Frederic Guillon, Simona Longo, Corrado Leone, Outi Paadar, Anastasia Leonenko. - University of Lapland: Arctic Centre, 2014. - 103 p.

12. Ritchey T. Morphological Gap-Analysis. Using GMA to find the $\Delta / \mathrm{T}$. Ritchey // Acta Morphologica Generalis. - 2013. - Vol. 2, No 2. - P. 1-15.

13. Денисик Г.I. Сучасні ландшафти заплави Південного Бугу та їх раціональне використання / Г.І. Денисик // Наукові записки [Вінницького державного педагогічного університету імені Михайла Коцюбинського]. Серія : Географія. - 2014. - Вип. 26. C. $5-11$.

14. Дезірон О.В., Мокін В.Б., Крижановський Є.М. Геоінформаційна система басейну річки Південний Буг та їі роль в прийнятті управлінських рішень // Водне господарство України. - 2006.- № 4.- С. 10-15.

15. Водні ресурси та якість річкових вод басейну Південного Бугу: Монографія / за ред. В.К. Хільчевського. - К.: Ніка-центр. - 2009. - 184 с.

16. Колодеєв С.І., Оцінка якості води верхньої частини басейну р. Південний Буг за гідрохімічними показниками / С.I. Колодеєв, М.В. Захарова // Український гідрометеорологічний журнал. - 2011. - № 9. - С. 151-157.

17. Магась Н.I. Оцінка сучасного антропогенного навантаження на басейн річки Південний Буг / Н.І. Магась, А.Г. Трохименко // Екологічна безпека. - 2013. - № 2(16). - С. $48-52$.

18. Хаєцький Г.С. Екологічні проблеми використання природних ресурсів річки Південний Буг / Г.С. Хаєцький // Наук. зап. Вінницького держ. пед. ун-ту. Сер. Географія. - 2009. - Вип. 19. - С. 118-125.

19. Екологічний атлас басейну річки Південний Буг / під ред. Мокіна В.Б., Крижановського Є.М., Марушевського Г.Б. - Вінниця: Чорноморська програма Wetlands International, 2009. - $19 \mathrm{c}$.

20. Козлов С. Экологический стандарт «Нибулона» - в действии! // Вечерний Николаев. - 2017. - №128(4041). - С. 5.

21. «НІБУЛОН» завершив черговий етап днопоглиблення Південного Бугу [Електронний ресурс] // Прес-центр Нібулону. - 2015. - Режим доступу: http://www.nibulon.com/news/novini-kompanii/nibulon-zavershiv-chergovii-etap-

dnopogliblennya-pivdennogo-bugu.html

22. Szałkiewicz E. Status of and Perspectives on River Restoration in Europe: 310,000 Euros per Hectare of Restored River / E. Szałkiewicz, S. Jusik, M. Grygoruk // Sustainability. 2018. - No. 10, 129. - P. 1-15. doi:10.3390/su10010129

23. Заява про екологічні наслідки проектної діяльності [Електронний ресурс] - Режим доступу: http://www.nibulon.com/uploads/files/Zayava_1.pdf.

24. В. Синявский. Компания "НИБУЛОН" выпустила в Южный Буг более двухсот тысяч экземпляров толстолобика, белого амура и карпа // Николаевские новости. 2017. - №137. - С. 3.

\section{REFERENCES (TRANSLATED AND TRANSLITERATED)}

1. Palamarchuk, M. M., \& Zakorchevna, N. B. (2001). The Water Fund of Ukraine. Kyiv: Nika-center (in Ukrainian).

2. Vishnevskii, V. \& Kosovets, O. (2003). Hydrological characteristics of the rivers of Ukraine. Kyiv: Nika-center (in Ukrainian).

3. The navigable potential of the Southern Bug. (2015). Retrieved from http://www.nibulon.com/news/novini-kompanii/sudnoplavnii-potencial-pivdennogobugu.html (in Ukrainian).

4. Information for the company's stakeholders (dredging works on the Southern Bug River). (2015). Retrieved from: http://www.nibulon.com/data/investiciina-diyalnist/dlyainvestoriv/informaciya-dlya-steikxolderiv-kompanii2.html (in Ukrainian). 
5. Shooting of the Southern Bug - a threat to the ecology of the Mykolaiv region. (2015). Retrieved from: http://www.nibulon.com/news/novini-kompanii/obmilinnya-pivdennogobugu-zagroza-dlya-ekologii-mikolaivskogo-regionu.html (in Ukrainian).

6. Lowry, T., Bright, J., Close, M., Robb, C. A., White, P. A., \& Cameron, S. G. (2003). Management Gap Analysis: A Case Study of Groundwater Resource Management in New Zealand. International Journal of Water Resources Development, 19, 579-592 (in English). doi:10.1080 / 0790062032000161382.

7. Day, G. S. (2011). Closing the Marketing Capabilities Gap. Journal of Marketing, 75, 183-195 (in English).

8. Jennings, M. D. (2000). Gap analysis: concepts, methods, and recent results. Landscape Ecology, 15, 5-20 (in English).

9. Ariño, A. H., Chavan, V., \& Otegui, J. (2016). Best Practice Guide for Data Gap Analysis for Biodiversity Stakeholders. Pamplona: Global Biodiversity Information Facility (in English).

10. Scott, M. J., Davis, F. W., Cusuti, B., Noss, R., Butterfield, B., Groves, C., Anderson, H., Caicco, S., D'Erchia, F., Edwards, T. C., Ulliman, J., \& Wright, R. G. (1993). GAP Analysis: A Geographic Approach to the Protection of Biological Diversity. Wildlife Monographs, 123, 1-41 (in English).

11. Tedsen, E., Riedel, A., Weingartner, K., Azzolini, R., Guillon, F., Longo, S., Leone, C., Paadar, O., \& Leonenko, A. (2014). Gap Analysis Report. Preparatory Action, Strategic Environmental Impact Assessment of Arctic. University of Lapland: Arctic Center (in English).

12. Ritchey, T. (2013). Morphological Gap-Analysis. Using GMA to find the $\Delta$. Acta Morphologica Generali, 2(2), 1-15 (in English).

13. Denisik, G. I. (2014). Modern landscapes of the floodplain of the Southern Bug and their rational use. Scientific notes [Vinnytsia State Pedagogical University named after Mikhail Kotsiubynsky]. Series: Geography, 26, 5-11 (in Ukrainian).

14. Desiron, O. V., Mokin, V. B., \& Kryzhanovsky, Ye. M. (2006). Geoinformation system of the basin of the Southern Bug River and its role in making managerial decisions. Water management of Ukraine, 4, 10-15 (in Ukrainian).

15. Khilchevsky, V. K. (Ed.). (2009). Water resources and quality of river basins of the Southern Bug River. Kyiv: Nika-center (in Ukrainian).

16. Kolodeev, E. I., \& Zakharova, M. V. (2011). Estimation of water quality of the upper part of the Pivdennyi Buh river basin by hydrochemical indicators. Ukrainian Hydrometeorological Journal, 9, 151-157 (in Ukrainian).

17. Magas, N. I., \& Trochimenko, A. G. (2013). Estimation of modern man-made load on the river basin of the Southern Bug. Ecological safety, 16(2), 48-52 (in Ukrainian).

18. Khayetsky, G. S. (2009). Environmental problems of using natural resources of the Southern Bug. Scientific notes [Vinnytsia State Pedagogical University named after Mikhail Kotsiubynsky]. Series: Geography, (19), 118-125 (in Ukrainian).

19. Mokin, V. B., Kryzhanovsky, Y. M., \& Marushevsky, G. B. (Eds.). (2009). Ecological atlas of the basin of the Southern Bug River. Vinnytsya: Wetlands International Black Sea Program (in Ukrainian).

20. Kozlov, S. (2017). Environmental standard "Nibulon" - in action! Vecherny Nikolayev, No.128, p. 5 (in Russian).

21. "NIBULON" completed the next stage of the deepening of the Southern Bug. (2015). Retrieved from http://www.nibulon.com/news/novini-kompanii/nibulon-zavershivchergovii-etap-dnopogliblennya-pivdennogo-bugu.html (in Ukrainian)

22. Szałkiewicz, E., Jusik, S., Grygoruk, M. (2018). Status of and Perspectives on River Restoration in Europe: 310,000 Euros per Hectare of Restored River. Sustainability, 129(10), 1-15 (in English). doi:10.3390/su10010129

23. Environmental Impacts Statement. (2015). Retrieved from: http://www.nibulon.com/uploads/files/Zayava 1.pdf (in Ukrainian). 
24. Sinyavsky, V. (2017). The company "NIBULON" released in the Southern Bug more than two hundred thousand copies of silver carp, white carp and carp. Nikolaevskie Novosti, No. 137, p. 3 (in Russian).

Text of the article was accepted by Editorial Team 03.07.2018

М.М. Радомська, О.В. Рябчевський, В.В. Вологжаніна, В.В. Ковальська АНАЛІЗ ПРОГАЛИН В ОЦІНЦІ ВПЛИВІВ НА НАВКОЛИШНЕ СЕРЕДОВИЩЕ ПРОЕКТУ ДНОЗАГЛИБЛЕННЯ НА Р. ПІВДЕННИЙ БУГ

Анотація. У статті розглянуто трансформацію екосистеми річки Південний Буг у зв'язку з реалізацією проекту з відродження судноплавства 3 точки зору непрямого впливу на навколишне середовище. Метод аналізу прогалин, що широко використовується у різних галузях науки, був застосований для визначення наслідків днопоглиблювальних робіт у басейні річки, що не отримали належної уваги при виконанні екологічної оцінки. Аналіз показав, що, незважаючи на низку важливих переваг, включаючи сприяння розвитку виробництва сільськогосподарських та будівельних матеріалів, зменшення обсягу наземних вантажоперевезень та збільшення надходжень до місцевого бюджету, реалізація проекту призведе до додаткових негативних наслідків, які не були розглянуті в офіційному процесі оцінки впливів на навколишнє середовище. Найважливішими проблемами, що потребують подальшої уваги та пом'якшення, є інтенсифікація ерозійних процесів, зміни якості повітря та води, зміна біоценозу річки та клімату району, а також утилізація видобутих донних відкладів.

Ключові слова: біоценоз; оцінка впливу на навколишнє середовище; аналіз прогалин; днозаглиблювальні роботи; поводження 3 відходами; трансформація екосистем

\section{Радомська Маргарита Мирославівна}

кандидат технічних наук, доцент, доцент кафедри екології Національного авіаційного університету

Адреса робоча: Україна, м. Київ, просп. Космонавта Комарова, 1

Тел.: 0674983873 e-mail: m.m.radomskaya@gmail.com

ORCID ID 0000-0002-8096-0313

\section{Рябчевський Олег Володимирович}

асистент кафедри екології Національного авіаційного університету

Адреса робоча: Україна, м. Київ, просп. Космонавта Комарова, 1

Тел.: 0978260803 e-mail: arnem@ukr.net

ORCID ID 0000-0002-5901-4365

\section{Вологжаніна Вероніка Вікторівна}

аспірант кафедри екології Національного авіаційного університету

Адреса робоча: Україна, м. Київ, просп. Космонавта Комарова, 1

Тел.: 0506911185 e-mail: ver.vologzhanina@gmail.com

\section{Ковальська Вікторія Володимирівна}

студент кафедри екології Національного авіаційного університету

Адреса робоча: Україна, м. Київ, просп. Космонавта Комарова, 1

Тел.: 0506911185 e-mail: vika_kovalska98@ukr.net

ORCID ID 0000-0002-5489-7787 